УДК 338.48 (477.72)

DOI https://doi.org/10.32851/2708-0366/2021.6.2

Стукан T.M.

молодший науковий співробітник, Херсонський державний аграрно-економічний університет ORCID: https://orcid.org/0000-0002-8682-1832

Осадчий А.A.

молодший науковий співробітник, Херсонський державний аграрно-економічний університет ORCID: https://orcid.org/0000-0002-5301-2211

Stukan Tatyana, Osadchiy Anatolii Kherson State Agrarian and Economic University

\title{
АНАЛІЗ РИНКУ ТУРИСТИЧНИХ ПОСЛУГ ХЕРСОНЩИНИ
}

\section{ANALYSIS OF THE MARKET OF TOURIST SERVICES OF KHERSONSHINA}

У статті визначено наявну кількість туристів, які користуються послугами туроператорів для подорожей територією Украӥни та поза ї̈ межами. Здійснено аналіз показників, шо характеризують діяльність суб'єктів туристичної сфери Херсонської області. Виділено перелік туристичних операторів, які забезпечують надання туристичних послуг виключно по Херсонщині, тим самим здійснюючи популяризацію внутрішнього туризму. Визначено, щуо промоція внутрішнього туризму турагентствами здійснюється за рахунок розроблених маршрутів, які розкривають історичні, культурні та природні надбання регіону, де завжди знайдуться цікаві аспекти для українських й іноземних туристів. Наведено перелік передумов щзодо розвитку туристичних операторів області, щзо призведе до їх кількісного зростання та розширення переліку туристичних продуктів, а також до зростання економіки та надходження інвестиційних коштів до регіону.

Ключові слова: внутрішній туризм, туристичні локащї, ринок послуг туроператорів.

В статье определено имеющееся количество туристов, пользующихся услугами туроператоров для путешествий по территории Украины и за ее пределами. Проведен анализ показателей, характеризуюших деятельность субъектов туристической сферь Херсонской области. Выделен перечень туристических операторов, которые обеспечивают предоставление туристических услуг исключительно по региону, тем самьм осуществляя популяризацию внутреннего туризма. Определено, что продвижение внутреннего туризма турагентствами осуществляется за счет разработанных маршрутов, которые раскрывают исторические, культурные и природные достояния региона, где найдутся интересныле аспекты для туристов. Приведен перечень предпосылок к развитию туристических операторов Херсонской области, что приведет к их количественному росту $u$ расширению их перечня туристических продуктов, а также к поступлению инвестиционных средств в регион.

Ключевые слова: внутренний туризм, туристические локации, рынок услуг туроператоров.

The article defines an existing number of tourists who use the services of tour operators to travel by the territory of Ukraine and beyond. The analysis of indicators that characterize the activities of the tourism sector of the Kherson region is carried out. A distinguished list of tourist operators, which ensure the provision of tourist services exclusively in the Kherson region, thereby exercising popularization of domestic regional tourism. It is determined that the promotion of domestic tourism travel agencies is carried out at the expense of developed routes and tours that reveal the historical, cultural, and the natural property acquisitions, where there will always be interesting aspects of both Ukrainian and foreign tourists. Their advertising 
takes place through official sites, Internet platforms, conducting tourist forums, exhibitions, festivals, etc. It is revealed that the strengthening of the significance of tourism businesses in the development of domestic tourism of the region takes place through the development of tourist projects involving local self-government bodies, since improving the tourist infrastructure of the region possible through the cooperation of all subjects of interest in this process. Characterized tourist projects, the creation of which for the Kherson region will lead to an increase in demand for an internal tourist product, will attract potential investors to investing funds and development of their own business, will create additional jobs for the local population. Also, the article presents the main list of prerequisites for the development of tourist operators of the Kherson region, which will lead to their quantitative growth and expanding their list of tourist products and thus to increase the economy and incurred investment funds to the region. An analyzed list of top 20 brands and top 6 location routes of the region, which are today in demand in the field of services providing travel agencies of Kherson region and are presentation tourist facilities that reveal all cultural, historical, natural resource, gastronomic, hotel, hotel. Restaurant potential of the Tavria region. It has been proved that joint efforts of all levels of government and all tangential subjects to the tourism sector may choose that vector of activity, which will lead to the creation of proper infrastructure objects and tourist locations in the region, and their effective promotion will increase the tourist flows of the inbound and Outbound tourists.

Key words: domestic tourism, tourist locations, tour operators market.

Постановка проблеми. У період постійних трансформаційних змін економіки, що відбуваються як на загальнодержавному, так і на регіональному рівні, у всіх сферах виробничої діяльності слід знаходити або інноваційно покращувати існуючі напрями стратегічного розвитку регіонів. Сьогодні в умовах світової коронакризи внутрішній туризм стає економічно ефективним та набуває ознак однієї з провідних, прибуткових та найбільш динамічних сфер народного господарства. Туризм взаємодіє з більш ніж 50-ма сферами, серед них: культура, мистецтво, наука, освіта, спорт, готельно-ресторанна справа, медицина, торгівля, транспорт, зв'язок, фінанси, розваги, будівництво тощо. Усе це спонукає до поєднань і комбінацій, які призводять до створення нових напрямів внутрішнього туризму. Для промоції кожного з напрямів існує необхідність у розвитку та розширенні регіонального ринку туроператорів, які будуть зацікавлені в популяризації туристичного продукту, а ефективно розроблена пропозиція створить передумови до формування попиту і забезпечить їм отримання прибутку. Розвиток регіонального внутрішнього туризму спрямований на пропагування та популяризацію інвестиційної привабливості регіону через створення вигідних економічних умов, локацій, об'єктів, відведення територій для потенційних інвесторів. Тому суб'єкти туристичного бізнесу та регіональні органи місцевого самоврядування повинні об'єднати свої зусилля для створення якісного туристичного продукту на основі раціонального використання туристичних ресурсів регіону та визначення зон пріоритетного розвитку туризму шляхом туристичного районування області. Для того щоб перейти до реалізації даної мети, існує необхідність у здійсненні аналізу ринку туроператорів Херсонщини як чинника стимулювання популяризації внутрішнього туризму як на загальнодержавному рівні, так і на міжнародному.

Аналіз останніх досліджень і публікацій. Науковцями, як вітчизняними, так i зарубіжними, протягом тривалого часу приділяється значна увага дослідженню питання регіонального туризму, його особливостям, стану та перспективним напрямам сталого розвитку. Проблематика, з якою стикається вітчизняна туристична галузь, досліджена в працях таких учених, як Г. Бак, Л. Богуш, В. Данильчук, О. Кальченко, В. Цибух, І. Школа та ін. Особливості й організацію діяльності туроператорів, характеристику технологічних процесів проєктування, розроблення та збут туристичного продукту, визначення критеріїв оцінки туристичного обслуговування висвітлено в роботах В. Брича, О. Гарбера, С. Гунька, В. Даниленко-Кульчицької, М. Домбровського, С. Крамарчука, О. Оливка та ін. Водночас, зважаючи на постійні трансформа- 
ційні зміни, які відбуваються у світовій економіці, від чого зазнають збитків усі галузі народного господарства (і туристична сфера не виняток), виникає потреба у вивченні питання аналізу ринку туроператорів на регіональному рівні як чинника стимулювання популяризації внутрішнього туризму.

Формулювання цілей статті. Метою дослідження $є$ здійснення аналізу ринку туристичних послуг Херсонської області та визначення передумов щодо розвитку суб'єктів туристичного бізнесу регіону, що призведуть до їх кількісного зростання та розширення їх переліку туристичних продуктів.

Виклад основного матеріалу. На сучасному етапі розвитку України та іiі регіонів туризм відіграє одну з ключових ролей у формуванні їхніх конкурентних переваг, а також виступає чинником стимулювання розвитку супутніх видів діяльності та фактором надходження фінансових коштів, сприяє залученню інвесторів і створенню додаткових робочих місць. Хоча останнім часом соціально-економічна, політична та епідеміологічна ситуація знаходиться у нестабільному стані, туристична галузь намагається розвиватися і тим самим впливати на інфраструктуру регіонів. Сьогодні державні адміністрації південних регіонів України (Одеської, Миколаївської та Херсонської областей) убачають перспективу в розвитку внутрішнього туризму регіону через об'єднання у цьому напрямі спільних зусиль та залучення до цього процесу абсолютно всіх суб'єктів туристичного бізнесу. I першим кроком на цьому шляху стало підписання Меморандуму щодо співпраці у сфері розвитку туристичної галузі. Документом передбачено створення сприятливих організаційних та економічних умов для розвитку туристичного потенціалу Миколаївської, Одеської та Херсонської областей, раціональне використання туристичних ресурсів, підвищення конкурентоспроможності регіонів на міжнародному туристичному ринку, у тому числі через підтримку пріоритетних напрямів туристичної діяльності, залучення інвестицій у розбудову туристичної інфраструктури та індустрії гостинності, розширення міжнародного та міжрегіонального співробітництва.

Перш ніж переходити до аналізу надання туристичних послуг на регіональному рівні доцільним є визначення наявної кількості туристів по всій Україні, яких обслуговують туроператори, дані наведено в табл. 1.

Таблиця 1

Оцінка кількісного складу туристів, які отримали туристичні послуги через туроператорів за 2015-2019 рр.

\begin{tabular}{|l|c|c|c|c|c|c|c|}
\hline & \multicolumn{5}{|c|}{ Роки } & \multicolumn{2}{c|}{$\mathbf{2 0 1 9}$ р. у $\%$ до } \\
\hline & $\mathbf{2 0 1 5}$ & $\mathbf{2 0 1 6}$ & $\mathbf{2 0 1 7}$ & $\mathbf{2 0 1 8}$ & $\mathbf{2 0 1 9}$ & $\mathbf{2 0 1 5} \mathbf{p .}$ & $\mathbf{2 0 1 8} \mathbf{p .}$ \\
\hline $\begin{array}{l}\text { Кількість турис- } \\
\text { тів, які обслугову- } \\
\text { валися туроперато- } \\
\text { рами та тураген- } \\
\text { тами, усього }\end{array}$ & 2019576 & 2549606 & 2806426 & 4557447 & 6132097 & у 3 рази & 134,55 \\
\hline у т. ч. & 15159 & 35071 & 39605 & 75945 & 86840 & у 5,7 разів & 114,35 \\
\hline $\begin{array}{l}\text { в'їзні (іноземні) } \\
\text { туристи }\end{array}$ & 1647390 & 2060974 & 2289854 & 4024703 & 5524866 & у 3 рази & 137,27 \\
\hline виїзні туристи & 357027 & 453561 & 476967 & 456799 & 520391 & 145,76 & 113,92 \\
\hline внутрішні туристи & & & & & & \\
\hline
\end{tabular}

Джерело: сформовано за даними [4; 8; 9]

Проаналізований період 2015-2019 рр. показує позитивну динаміку до зростання кількості туристів, які отримали послуги через туроператорів та турагентів. Такий 
стан свідчить про довіру туристів до даних суб'єктів туристичної сфери та зростання попиту на їхній туристичний продукт. Окрім того, можна говорити, що 2016 р. $є$ початком періоду, з якого спостерігається зростання туристів за всіма трьома потоками: в 'їзні, виїзні та внутрішні. Порівнюючи 2019 р. $з 2015$ р., зростання кількості туристів, які віддали перевагу туроператорам, відбулося у три рази, а порівняно з 2018 р. - на $34,55 \%$. Якщо аналізувати надання послуг туроператорами за потоками туристів, то найбільша частка припадає на обслуговування виїзних туристів: їх кількість у 2019 р. порівняно з 2015 р. зросла майже у три рази. Спостерігається позитивна динаміка і по в'їзних (іноземних) туристах: у 2019 р. відвідали Україну через туроператорів 86840 осіб, що у 5,7 рази більше, ніж у 2015 р., та на 14,35\% більше, ніж у 2018 р. Зросла і кількість туристів, що подорожують Україною: якщо у 2015 р. їх зафіксовано 357027 осіб, то в 2019 р. - 520391 особа, що на 45,76\% більше. Проаналізована кількість туристів, що скористалися послугами суб'єктів туристичної діяльності, показує позитивну динаміку зростання туристичних потоків, тому слід формувати систематичний підхід до здійснення промоції туристичної сфери та популяризації внутрішнього туризму, особливо це стало актуальним у 2020 р., коли туристична сфера опинилася в полоні корона кризи, і для того, щоб зберегти попередні показники турагентствам слід розвивати нові напрями, які будуть спрямовані на зростання внутрішньотуристичних потоків.

Сьогодні ринок туристичних агенцій Херсонської області налічує близько 160 суб'єктів. Їхня робота так чи інакше пов'язана з безпосереднім здійсненням діяльності, яка спрямована на формування конкурентних переваг регіону за рахунок створення нових туристичних маршрутів та каналів комунікацій між в'їзними та виїзними туристами області. Стан туристичної сфери та діяльність туристичних агенцій відображається через показники, що характеризують та зумовлюють їх функціонування; по Херсонській області дані за 2018 та 2019 рр. наведено в табл. 2

Аналізуючи дані табл. 2 за 2018-2019 рр., бачимо скорочення кількості офіційно зареєстрованих суб’єктів туристичної діяльності по Херсонській області на 12,5 в. п. Це зумовило зменшення кількості штатних працівників на 5,8 в. п., де скорочення торкнулося і середньооблікової кількості штату, що має вищу або середню спеціальну освіту в галузі туризму, на 17,9 в. п. Стосовно отриманого доходу туристичними операторами та турагентами, то в 2019 р. порівняно з 2018 р. відбулося його збільшення на 3 077,1 тис грн, або на 8,2 в. п. Це відбулося за рахунок зростання кількості туристів, як в'їзних, так і виїзних, а також через підвищення вартості туристичних путівок, і в 2019 р. порівняно з 2018 р. збільшення відбулося на 5,9 в. п. Аналізуючи дохідну частину суб'єктів туристичного бізнесу від екскурсійної діяльності, спостерігаємо зменшення доходу на 725,7 тис грн у 2019 р. порівняно з 2018 р., або на 67,56 в. п. Це спричинено зменшенням кількості туристів, які обслуговуються туроператорами та тур агентами, на 1122 особи, а ті, хто скористався послугами, серед них відвідування екскурсійних марштурів не користувалося попитом. За даними таблиці видно, що дохід від продажів путівок громадянам України для подорожей країною зріс на 275,3 тис грн, або на 3,4 в. п., за аналізований період. Отже, можна говорити про надання переваги з боку туристів подорожам країною, що веде до пріоритетності у розвитку внутрішнього туризму регіону через створення інфраструктурних об'єктів, розроблення локальних туристичних маршрутів, які б розкривали красу Таврійського краю.

Для популяризації внутрішнього туризму Херсонської області доцільно вибрати такий канал комунікації між туристом та туристичним об'єктом, як туроператори. Туристичні оператори - це компанії, діяльність яких спрямована на організацію та забезпечення створення туристичного продукту, його просування, а також реалізацію та надання туристичних послуг [1]. Нами виділено низку туристичних агенцій, діяль- 
ність яких спрямована на промоцію регіонального туризму саме на Херсонщині або на розвиток вітчизняного туризму, де йде представлення регіонального туристичного продукту.

Таблиця 2

\section{Показники, що характеризують діяльність суб'сктів туристичної сфери Херсонської області за 2018 та 2019 рр.}

\begin{tabular}{|c|c|c|c|c|}
\hline \multirow[t]{2}{*}{ Показники } & \multicolumn{2}{|c|}{ Роки } & \multicolumn{2}{|c|}{ Відхилення } \\
\hline & 2018 & 2019 & $\begin{array}{l}\text { Абсолютне } \\
(+/-)\end{array}$ & $\begin{array}{c}\text { Відносне } \\
(\%)\end{array}$ \\
\hline $\begin{array}{l}\text { Кількість суб’єктів туристичної діяльності - } \\
\text { усього, од. }\end{array}$ & 16 & 14 & -2 & 87,50 \\
\hline $\begin{array}{l}\text { Середньооблікова кількість штатних } \\
\text { працівників - усього, осіб }\end{array}$ & 52 & 49 & -3 & 94,23 \\
\hline $\begin{array}{l}\text { iз них } \\
\text { - мають вищу або середню спеціальну освіту } \\
\text { в галузі туризму }\end{array}$ & 28 & 23 & -5 & 82,14 \\
\hline - жінки & 42 & 28 & -14 & 66,67 \\
\hline - особи до 30 років & 5 & 4 & -1 & 80,00 \\
\hline Дохід від надання туристичних послуг, тис грн & 36123,6 & 39200,7 & 3077,1 & 108,52 \\
\hline $\begin{array}{l}\text { У т. ч. } \\
\text { - від екскурсійної діяльності, тис грн }\end{array}$ & 1074,1 & 348,4 & $-725,7$ & 32,44 \\
\hline $\begin{array}{l}\text { Витрати на послуги сторонніх організацій, } \\
\text { що використовуються під час виробництва } \\
\text { туристичного продукту, тис грн }\end{array}$ & 8042,9 & 4767,6 & $-3275,3$ & 59,28 \\
\hline $\begin{array}{l}\text { Кількість туристичних путівок, реалізованих } \\
\text { туроператорами та турагентами, од. }\end{array}$ & 4628 & 3343 & -1285 & 72,23 \\
\hline $\begin{array}{l}\text { Вартість туристичних путівок, реалізованих } \\
\text { туроператорами та турагентами, тис грн }\end{array}$ & 35049,5 & 37115,6 & 2066,1 & 105,89 \\
\hline $\begin{array}{l}\text { iз них } \\
\text { - громадянам України для подорожей } \\
\text { Україною }\end{array}$ & 8095,9 & 8371,2 & 275,3 & 103,40 \\
\hline $\begin{array}{l}\text { Кількість туристів, обслугованих } \\
\text { туроператорами та турагентами, осіб }\end{array}$ & 5330 & 4208 & -1122 & 78,95 \\
\hline
\end{tabular}

Джерело: сформовано за даними [4; 8; 9]

Сьогодні вдалим прикладом серед туроператорів Херсонщини є компанія Finist Tour, яка має Інтернет-платформу, де відбувається популяризація внутрішнього туризму регіону через створення та продаж в’їзних турів регіоном. На платформі представлено туристичні об'єкти таких районів області, як Каховський, Бериславський, Чаплинський, Генічеський та Голопристанський, а також міст Нова Каховка, Каховка, Берислав, Гола Пристань, Таврійськ та Херсон [5].

Локальний туристичний оператор Finist Tour розробив шість напрямків в 'їзних турів Херсонщиною, які зараз є популярними в плані представлення всього Таврійського краю [5]:

- екологічний тур «Таврійська Робінзонада»;

- історично-паломницький тур «Місцями козацької слави»;

- екологічний тур «Багатолика Таврія»;

- тур вихідного дня «На перехресті світів та цивілізацій»; 
- винний тур «Подорож за таємницями вина»;

- соляна дорога.

Створені тури розкривають історичні, культурні, та природні надбання регіону, де завжди знайдуться цікаві аспекти як для українських, так і іноземних туристів. Наочно шість напрямків в’їзих турів Херсонщиною представлено на рис. 1.

Охопленість території Херсонської області в'їзними турами становить п’ять районів, шість міст та сім об'єднаних територіальних громад регіону. Вони поєднують у собі цілий комплекс інфраструктурних туристичних об'єктів Херсонщини та популяризують їх, спрямовують до сталого розвитку такі види туризму, як зелений, внутрішній, рекреаційно-курортний, водний, сільський, екологічний, історико-культурний тощо. Місцевість запропонованих напрямків $є$ й інвестиційно привабливою в плані розбудови та доповнення іiі новими перспективними інфраструктурними локаціями.

За перспективним планом планується створення Лікувально-оздоровчого комплексу біля Лемурійського озера, який забезпечить процедури 3 лікарською глиною даного озера; Музею живої історії туристичного об'єкта «Олешківська Січ», де для туристів проводитимуться інтерактивні екскурсії, майстер-класи народних промислів та ремесел, і низку інших об’єктів, значення яких для області є важливим.

Ще одним туроператором, який працює на ринку надання туристичних послуг, пов'язаний із популяризацією та розвитком вітчизняного внутрішнього туризму, $\epsilon$ «АНГА Тревел». Дане турагетнство володіє досвідом роботи в реаліях забезпечення промоції внутрішнього туризму. Сьогодні його Інтернет-платформа з реалізації туристичного продукту пропонує 63 екскурсії одного дня, 144 маршрути по Україні, які включають тури в Буковель на шкільні канікули, у Карпати та по Закарпаттю, маршрут «Херсонщина вражає» тощо [6].

100\%-ву спрямованість на забезпечення розвитку внутрішнього туризму та його промоцію має Центр туризму «ХерсON». Даний суб'єкт туристичної галузі пропонує для туристів тури вихідного дня по Україні, поїздки південною частиною країни, корпоративний відпочинок, міські екскурсії Херсонщиною та різного роду активності. Центр туризму «ХерсON» розробив понад 100 авторських турів, маршрутів, екскурсійних програм визначними місцями Херсонської області, України та з урахуванням туристичної специфіки нашої країни. Окрім цього, туристичне агентство забезпечує різного роду активності, які можна спробувати, подорожуючи Херсонщиною. Центр туризму «ХерсON» також розробив прямі маршрути - тури вихідного дня для подорожей Херсонською областю для таких міст України, як Запоріжжя, Одеса, Київ, Дніпро, Харків. Користуються неабияким попитом серед туристів екскурсії до біосферного заповідника «Асканія-Нова» з виїздом у степ, до Актовського і Арбузинського каньйонів, до Херсонського гранд-каньйону, відвідування єдиного історичного шато в Україні - «Шато Трубецького», рожеві озера, сафарі по бездоріжжю на Кінбурнській косі, найбільша пустеля в Свропі - Олешківські піски, прогулянка на байдарках, сап-бордах по плавнях р. Дніпро, екскурсія «Херсон де масон» тощо [7].

Також Центр туризму «ХерсON» активно працює в напрямі розвитку гастрономічного туризму Херсонщини. Турагентством розроблені такі маршрути, популярність яких з кожним роком зростає. До переліку затребуваних гастрономічних і винних турів Півдня України відносять: «Шато Трубецького», «Устриці Скіфії», «Лиманська коза» - для любителів екопродукції та крафтових сирів, екскурсія по виробництву та дегустація продукції заводу «Таврія», дегустація натуральних та екологічних вин без консервації з шато Курінь [7].

Турагенції Херсонщини сформували перелік 20 брендових місць регіону, локаційних маршрутів, які обов’язково слід відвідати, приїхавши до області, і наступного разу повернутися для того, щоб оцінити, а що ж змінилося. Тож кращі ТОП-20 ідей, чим же 
зайнятися на Херсонщині: побувати на сафарі в «Асканія-Нова» або на Кінбурні; покупатися в гарячому джерелі; відвідати рожеві озера; виїхати на о. Джарилгач; зробити селфі з маяком; скуштувати сіль на Кінбурні; прогулятися пішохідною екскурсією по херсонським колоритним кварталам, дворикам, вуличкам та провулкам; побачити найбільший музейний експонат в Україні - скелет гігантського кита фінфала; наповнити флягу водою зі степового водоспаду; пробратися байдаркою крізь вузькі протоки херсонських джунглів; відвідати найбільшу в Європі пустелю - Олешківські піски; спуститися з найвищого бархану Олешківських пісків на льодянці; з'їсти кавун; прогулятися історичним центром м. Херсон; кинути монету у колодязь фортеці; відвідати «Італію» в Херсоні; здійснити подорож довкола Херсона на яхті; відвідати Міжнародний театральний фестиваль «Мельпомена Таврії»; скуштувати варення з помідорів або зелених волоських горіхів. Як бачимо, Херсонщина різноманітна, насичена різними природними, культурними, історичними, гастрономічними локаціями, які спонукають туристів хоча б раз відвідати їх. Тому турагенствам пропонується широке поле для розширення свої туристичних послуг, адже комбінація, поєднання не поєднуваного, креативність - це основна «фішка» внутрішнього туризму, адже споживачу перш за все треба дати емоцію, яку він запам'ятає, і чим яскравішою та неординарнішою вона буде, це буде перевагою суб'єкта туристичного бізнесу над своїми конкурентами.

Із проведеного аналізу турагенцій Херсонщини бачимо локаційно широкий перелік турів, екскурсій та маршрутів, які вони пропонують, але водночас для їх постійного розвитку слід розширювати та вдосконалювати туристичну інфраструктуру регіону. Регіон має вихід до морів, що є сприятливим середовищем для розведення марикультур, це формує всі передумови для посилення роботи у напрямі розвитку мідійно-устричного напряму і призведе до створення ще одного маршруту в гастротуризмі, який буде затребуваний серед відвідувачів. Це стане однією з передумов виходу внутрішнього туризму регіону на якісно новий рівень.

Посилення значимості суб'єктів туристичного бізнесу в розвитку внутрішнього туризму регіону відбувається через розроблення туристичних проєктів, долучаючи до цього процесу органи місцевого самоврядування, адже поліпшення туристичної інфраструктури регіону можливе через співпрацю всіх суб'єктів, зацікавлених у цьому процесі. Першочерговим для Херсонщини є подовження тривалості туристичного сезону (сьогодні це період із травня по вересень), доцільно зробити його протягом усього року. Це можливо зробити спочатку локаційно, вибравши найбільш популярні туристичні місця, а потім поступово розширюватися по всій території області.

Херсонська державна обласна адміністрація почала рухатися у цьому напрямі й у 2021 р. на Всеукраїнському форумі «Україна 30. Інфраструктура» анонсувала реалізацію проєкту La Perla Azzurra, який буде знаходитися на узбережжі Чорного моря між селищами Приморське Голопристанського району та Лазурне Скадовського району. Даний проєкт уже підтриманий на державному рівні, а Кабінет Міністрів України визначив його одним із пріоритетних на Херсонщині до 2023 р. La Perla Azzurra - це високоякісний комплекс із надання туристичних та розважальних послуг цілорічного функціонування, з відповідною інфраструктурою, зручною та доступною локацією та повним спектром бальнеологічних і лікувально-курортних послуг. Площа земельної ділянки, яку виділили під проект, становить 596,1 га, із них 300 га буде відведено під будівництво готелів та апартаментів, аквапарку, СПА-комплексів, ресторанів, яхт-клубів, котеджних кварталів, пансіонатів і науково-виробничого комплексу з розведення мальків риб. Комплекс одночасно зможе розмістити близько 30 тис осіб. Дана локація стане і хорошою зоною для інвестора, саме під нього на площі комплексу під забудову пропонується 17 земельних ділянок.

Тобто можна з упевненістю сказати, що даний локаційний об'єкт потрапить до карти туристичних послуг регіональних туроператорів, а попит на даний туристичний 
продукт тільки зростатиме. Реалізація та функціонування коплексу La Perla Azzurra розкриває нові можливості для популяризації внутрішнього туризму на Херсонщини та у цілому по країні. Проєкт суттєво вплине на туристичну та інвестиційну привабливість регіону та тієї території, де він працюватиме. Бюджети усіх рівнів від комплексу La Perla Azzurra отримають збільшення надходження податків, а регіон - зростання туристичних потоків в 'їзних та внутрішніх туристів.

На узбережжі Азовського моря відбувається реалізація національного проєкту «Міжнародний бальнеологічний курорт «Еко-Містечко». Він передбачає відкриття багатофункціонального реабілітаційного центру InterMedicalEcoCity. Загалом реабілітаційний комплекс зможе приймати на лікування, реабілітацію та оздоровлення до 500 пацієнтів щодня та дасть змогу створити понад 1 тис робочих місць.

Два проєкти різнопланові, але є дуже важливими стратегічними об'єктами для регіону, і реалізація їх посилить конкурентні позиції Херсонської області в плані туристичної привабливості та дасть поштовх до створення умов для розвитку суб’єктів господарювання різного спрямування.

У березні 2021 р. у рамках проєкту «Південне узбережжя України: від дослідження до розвитку» представлено концепції розвитку туристичної сфери Херсонщини на прикладі двох курортних міст - Генічеська та Скадовська. Архітектори пропонують сучасний погляд на дані туристичні місця через створення й оновлення туристичної інфраструктури: переформатувати зони для відпочинку, структурувати міський простір, осучаснити берегову зону та впорядкувати ії в одному архітектурному концепті, а також створити нові локаційні об'єкти, які зможуть зацікавити туриста. Згрупований перелік проєктних пропозицій щодо змін в інфраструктурі для м. Генічеськ та м. Скадовськ представлено на рис. 1.

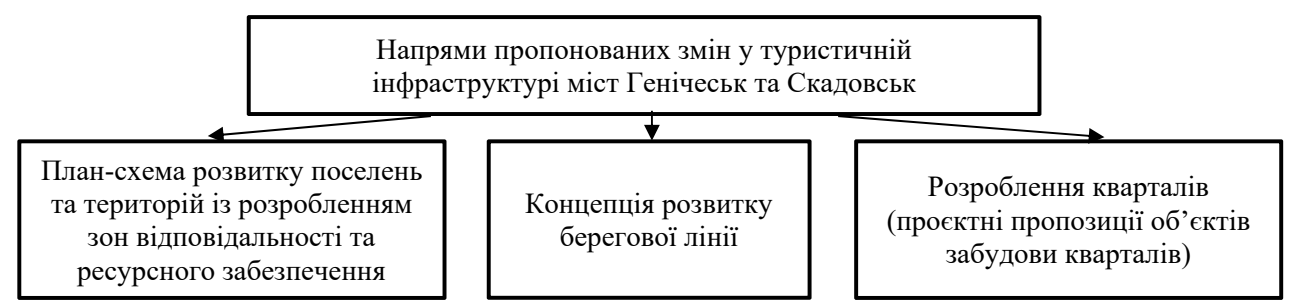

Рис. 1. Основні напрями, за якими планується здійснювати оновлення та розбудову туристичної інфраструктури міст Генічеськ та Скадовськ

Сьогодні за даними напрямами, що представлені на рис. 2, розроблені наочні макети, плани територій, квартальні забудови, які носять комплексний підхід, елементно доповнюючи один одного, і показують, як це буде компонуватися та реалізовуватися. Щоб це реалізувати, як у планах намічено до 2030 р., слід урахувати низку факторів: людський, фінансовий, інвестиційний. Людський фактор у цьому контексті - це наявність бажання у жителів та місцевої влади розвивати свою територію; фінансовий - пошук джерел, з яких будуть профінансовані інфраструктурні перетворення (цільові фонди, державні програми, співфінансування з місцевої громади); інвестиційний - полягає у створенні лояльних умов для бізнесу та виділенні земельних ділянок для майбутніх інверсорів.

До основних передумов розвитку суб'єктів туристичного бізнесу Херсонської області, що призведуть до їх кількісного зростання та розширення переліку туристичних продуктів і тим самим до зростання економіки регіону, належать [2]: 
- зростання доходів населення, які дадуть їм змогу, крім задоволення першочергових потреб, витрачати кошти на відпочинок;

- збільшення вільного часу для дозвілля;

- постійний розвиток туристичної інфраструктури та створення для цього організаційно-економічних передумов.

Висновки. Ринок туристичних операторів Херсонської області сьогодні має достатню кількість туристичних агенцій, більшою мірою їхні туристичні продукти спрямовані на виїзні тури до інших країн світу, а частка внутрішнього туризму $є$ незначною, це пов'язано з неокупністю даної статті витрат, недостатнім попитом на дані тури через брак позитивної інформації в інформаційному полі, недостатньо розвиненою інфраструктурою ресторанної та готельної сфер, занедбаністю історично-культурної спадщини регіону. Регіон має низку суб'єктів туристичної сфери, діяльність яких спрямована виключно на туристичні продукти регіону, і вони ефективно здійснюють їх промоцію через Інтернет-платформи, сайти, соціальні мережі, форуми тощо. Для того щоб їхня робота була ще більш ефективною, а регіон почав нарощувати темпи в розвитку туристичної галузі, слід посилити взаємодію всіх рівнів влади та зацікавлених суб'єктів бізнесу в цьому напрямі, зробити акцент на осучасненні туристичної інфраструктури, підготувати майданчики для інвесторів, розробити медіаплани щодо презентації тих змін, що будуть відбуватися, долучити до цього архітекторів, ландшафтних дизайнерів із креативним баченням міського, курортно-рекреаційного простору. Сьогодні, зважаючи на світову пандемію, спричинену коронавірусом, бізнес-процеси в туристичній сфері Херсонщини потребують налагодження комунікаційних каналів, які передбачають швидкість передачі й обміну інформацією, іiі актуальність, своєчасність отримання, адекватність і повноту, що тим самим забезпечує промоцію їхніх туристичних продуктів. Визначено, що найефективнішим каналом збуту на ринку послуг, що надають туристичні агенції Херсонщини, є мережа Інтернет, через яку безпосередньо відбувається планування, розроблення, організація та просування турів. Пошуковим сайтам стали більше довіряти в плані інформації, яку вони надають, аніж сім'ї і близьким. Тому такі інформаційно-комунікаційні технології відіграють ключову роль щодо підвищення конкурентоспроможності як туроператорів, так і туристичної сфери у цілому.

\section{Список використаних джерел:}

1. Вікіпедія. URL: https://uk.wikipedia.org/wiki/Туристичний_оператор (дата звернення: 17.03.2021).

2. Десятніков I. Стратегічні напрями розвитку туризму Черкаського регіону. Збірник наукових пращь ЧДТУ. Серія «Економічні науки». 2015. Вип. 40. Ч. І. 2015. С. 141-145.

3. Кирилов Ю.С., Грановська В.Г., Алєщенко Л.О. Формування конкурентних переваг суб'єктів туристичної галузі. Економіка АПК. 2020. № 5. С. 45-55.

4. Офіційний сайт Державної служби статистики України. URL: http://www.ukrstat.gov.ua/ operativ/operativ2007/tyr/tyr_u/potoki2006_u.htm (дата звернення: 17.03.2021).

5. Офіційний сайт компанії Finist Tour. URL: https://finisttour.com/ (дата звернення: 16.03.2021).

6. Офіційний сайт туристичного оператора «Анга Tревел». URL: https://anga.ua/pages/ about/history.html (дата звернення: 16.03.2021).

7. Офіційний сайт туристичного оператора «Центр туризму XepcON» URL: https://khers-on.com/ua/ (дата звернення: 21.03.2021).

8. Туристична діяльність в Україні у 2018 році : статистичний збірник / відп. за вип. O.O. Кармазіна. Київ : Державна служба статистики України. URL: https://ukrstat.gov.ua (дата звернення: 17.03.2021).

9. Туристична діяльність в Україні у 2019 році : статистичний збірник. Київ : Державна служба статистики України. URL: https://ukrstat.gov.ua (дата звернення: 17.03.2021). 


\section{References:}

1. Vilna entsyklopediia «Vikipediia» [Free encyclopedia «Wikipedia»]. Available at: https://uk.wikipedia.org/wiki/Туристичний_оператор (accessed 17 March 2021).

2. Desiatnikov I. (2015) Stratehichni napriamy rozvytku turyzmu Cherkaskoho rehionu [Strategic direct development of tourism in the Cherkasy region]. Zbirnyk naukovykh prats ChDTU. Seriia: Ekonomichni nauky, vol. 40, pp. 141-145.

3. Kyrylov Yu.Ye., Hranovska V.H., Alieshchenko L.O. (2020) Formuvannia konkurentnykh perevah subiektiv turystychnoi haluzi [Forming of competitive edges of subjects of tourist industry]. Economy of APK, vol. 5, pp. 45-55.

4. Oficijnyj sajt Derzhavnoji sluzhby statystyky Ukrajiny [Official site of the State Statistics Service of Ukraine]. Available at: http://www.ukrstat.gov.ua/operativ/menu/menu_u/ni.htm (accessed 17 March 2021).

5. Ofitsiinyi sait kompanii Finist Tour [Official site Finist Tour]. Available at: https://finisttour.com/ (accessed 16 March 2021).

6. Ofitsiinyi sait turystychnoho operatora Anha Trevel [Official site of tour operator Ang Travel]. Available at: https://anga.ua/pages/about/history.html (accessed 16 March 2021).

7. Ofitsiinyi sait turystychnoho operatora Tsentr turyzmu KhersON [Official website of the tourist operator Tourism Center Kherson]. Available at: https://khers-on.com/ua/ (accessed 21 March 2021).

8. Karmazin O.O. (2018). Turystychna diialnist v Ukraini u 2018 rotsi [Tourist activity in Ukraine in 2018]. Kyiv: Derzhavna sluzhba statystyky Ukrainy. Available at: https://ukrstat.gov.ua (accessed 17 March 2021).

9. Turystychna diialnist v Ukraini u 2018 rotsi [Tourist activity in Ukraine in 2018]. Kyiv: Derzhavna sluzhba statystyky Ukrainy. Available at: https://ukrstat.gov.ua (accessed 17 March 2021). 